\title{
Marketing Approach in Educational Institutions Management: Transformation and Development Management
}

\author{
Izida I. Ishmuradova ${ }^{1}$, Yulia L. Kamasheva ${ }^{2}$, Rimma R. Khanmurzina ${ }^{2}$, Oksana V. Borysova ${ }^{3}$, \\ Alexandr L. Makarov ${ }^{4}$, Ruteniya R. Denisova ${ }^{5}$, Natalia A. Kora ${ }^{5}$ \\ ${ }^{1}$ Department of Business Informatics and Mathematical Methods in Economics, Kazan (Volga Region) Federal University, Kazan, Russian Federation \\ ${ }^{2}$ Department of Pedagogical Psychology and Pedagogy, Kazan Innovative University named after V.G. Timiryasov, Kazan, Russian Federation \\ ${ }^{3}$ Department of Theory and Management Organization, Gzhel State University, Elektroizolyator, Russian Federation \\ ${ }^{4}$ Department of Physical Education, Ulyanovsk State Agrarian University named after P.A. Stolypin, Ulyanovsk, Russian Federation \\ ${ }^{5}$ Department of Psychology and Pedagogy, Amur State University, Blagoveshchensk, Russian Federation
}

\begin{abstract}
Received: 18/12/2020
Accepted: 19/03/2020

Published: 20/02/2020

Abstract

The relevance of this article is to study the market of educational services for preschool children, since education is the fundamental beginning, the Foundation of human socialization and the most important means of cultural communication between generations. In relation to the modern period of Russian education development, it is a close attention and control to all areas of educational activity, as well as a duty to the continuous development of each educational institution, including the modern specifics in the field of manage $0 \mathrm{ment}$, using a marketing approach. The purpose of the study is to investigate the practice of educational services consumption, using a marketing approach. Research methods: an online survey was used as a research method, which allows us most effectively to investigate the quality and specifics of educational services provided. Research results: the article examines the market of educational services for preschoolers, describes the quality of services offered in the view of consumers. Practices of educational services consumption are investigated. The novelty and originality of the research lies in the fact that the market of educational services was studied for the first time using a marketing approach. It shows that producers of additional educational services primarily focus on the cost of services in their advertising messages, and most educational centers use information about highly qualified teaching staff. It determines that the future of promoting educational services on the Internet belongs to social networks. The main semantic units of competitive advantages of educational institutions stated in the advertising message are identified: training program; cost; qualified personnel; individual approach; unique additional offer. The article shows that the choice of additional classes is extremely limited and does not meet the needs of modern parents. It is determined that choosing additional classes, following things are important for parents: strengthening the child's health, the appearance of new acquaintances, which directly affects the socialization of the child in society. It is shown that fewer students attend foreign language classes and music classes. There are quite interesting and rare wishes of parents for narrow specializations: gymnastics, theater Studio, classes with a speech therapist, social sections. It is revealed that the highest level of satisfaction the following characteristics of educational services showed: the location of the institution; the schedule; the result of a child's development after attending; the attitude of teachers to children. Practical significance: the data Obtained in this work can be used in marketing, social psychology, pedagogy, and age psychology.
\end{abstract}

Keywords: Educational services, Education market, The marketing approach in the management

\section{Introduction}

The modern educational space in Russia is undergoing dramatic changes. A prerequisite for social stability and normal functioning of any society is the existence of a common system of values, which includes common ideals, symbols, beliefs, morals, traditions, and norms of behavior [1 - 4]. A specific mechanism that ensures the sustainability and stability of society is social institutions, which are value-normative systems through which people's actions in vital areas are directed and controlled. It should be noted that the education system is one of the most important social institutions. This fact is proeceded by the fact that thanks to the education system, the socialization of the individual in society takes place [5-8]. The non-governmental education system as a social institution also occupies its niche in modern Russian society. This influences all levels of the educational space [9-13].

Thus, the relevance of this research is primarily because in the modern world, complex multi-valued processes of renewal occur daily, which qualitatively change the life of a person. The socio-cultural sphere, including the latest approaches to education, is no exception. This means that education, first, should be aimed at continuous and regular improvement of the person. This principle is embedded in almost all modern educational programs. The rapid interest of society in the field of education has led to a rapid growth of offers in the market of educational services. This also means increased competition in this environment. Competing organizations are forced to develop new marketing strategies and channels of marketing communication in order to make their product - an educational

Corresponding author: Izida I. Ishmuradova, PhD in Economics, Senior Lecturer of the Department of Business Informatics and Mathematical Methods in Economics, Kazan (Volga Region) Federal University, Kazan, Russian Federation. E-mail: izida-89@ mail.ru 
service-recognizable and, undoubtedly, attractive to their potential consumers [14-18]. Thus, it can be argued that the use of marketing in the management of educational institutions occupies one of the highest positions in the structure of the management apparatus in the institution. Thanks to the use of marketing, it is possible to conduct marketing research in the educational market, monitor competitors, monitor price offers, as well as launch new products and services to the market, generate consumer demand for them, and encourage customers to take action. Marketing is also an assistant in predicting trends in the overall development of the educational services market [19-23].

Along with the understanding of education as a social institution, we now have another relevant approach to consider education from the point of view of marketing [24-28]. In this context, education is understood as the production of educational services. Despite the importance of marketing in the field of modern educational processes, we cannot say that domestic educational institutions actively use it in their practice [29].

Marketing approach in the management of an educational institution can include many marketing operations and activities: development of organizational and managerial structure; conducting marketing research using both qualitative and quantitative methods; analysis of ready-made marketing reports on the assortment, price, consumer situation in the market; development of advertising strategies, corporate identity, advertising style, conducting advertising campaigns; development of marketing activities for the formation and promotion of the brand of an educational institution and groups of educational services [30-35].

\section{Materials and Methods}

An important stage of the research was the study of the second agent of the market-the consumer. Namely, the quality of educational services was evaluated here, according to the target audience. At this stage, the online survey method was used. Taking into account the fact that the field of marketing research has undergone many transformations in recent decades, the form of methods used in research has changed significantly. The very use of the Internet as a research tool opens up new possibilities for empirical sociology. When conducting surveys using traditional methods, the researcher is increasingly having trouble in collecting high-quality information from respondents, so now the online survey method is gaining popularity, which allows you to significantly reduce time, financial costs, as well as human resources. Thanks to the development of social networks, this type of survey solves even the most difficult tasks in the shortest possible time.

We also analyzed 72 electronic resources and more than 95 advertising messages with offers containing the same factors of competitiveness. The goal of content analysis is to identify the so-called competitive factors by analyzing advertising messages on official websites and social networks.

Putting forward their offer via Internet communication, institutions of preschool additional education cannot only control the demand for services online, but also bring new products to the market. We are talking about new products, according to the preferences of young parents, who, in turn, are advanced Internet users and are searching for the most suitable services for their child on the Internet. An important aspect is the presence of reviews and comments from real consumers on the site or in the social media community, because this directly affects the purchase decision.

Producers of additional educational services, first, focus in their advertising messages on the cost of services - 30\%. It can be argued that the price of educational services plays a crucial role in choosing a particular children's training or sports center. According to representatives of educational services, the cost has a decisive influence on the purchase of services in the conditions of financial instability in modern Russia. In this regard, the majority of educational institutions have invested in the content of their advertising messages a sense of relatively low cost of services compared to competitors; $25 \%$ of educational centers found it necessary to use information about highly qualified teaching staff in their advertising messages. Undoubtedly, this factor can be attributed not only to preschool educational services, but also to the advantage of any educational institution, whether it is a University or a school. The Training Program category accounts for $20 \%$ of the total number of identified competitive advantage categories. A considerable number of advertising appeals to consumers are sent with the message either about the uniqueness of the training program, or about an approved program that meets all state standards. An individual approach is found in $14 \%$ of advertising messages on electronic resources, which tells us that not all training organizations use an approach in their marketing activities, in which there is an unconscious pressure on the consumer by indicating that all the individual needs and requests of the child and parents are taken into account. Although, this is a powerful psychological technique in marketing.

The lowest number of advertising messages contained unique offers that distinguish educational centers from each other $-12 \%$. This is a huge omission, because an additional bonus or a completely unusual offer will not only stand out from the crowd of competitors, but also make the service exclusive and unparalleled in the market of educational services in this area.

The next task to be solved using content analysis was to determine the proportion of educational centers' presence on the Internet. A codifier was developed that reflected all possible electronic resources on which commercial organizations are placed to promote their services on the network. Thus, the majority of producers of additional educational services have a corporate community page in the social network Vkontakte41percentage, which is a huge plus, since Vkontakte promotion is a promising and effective tool for promotion, particularly in Russia. Then we have $37 \%$ of personal sites' presence in organizations. As we can see, the indicators are not the saddest, because, despite the digital age, half of Russian companies do not have their own websites, although the site is the business card and face of the organization. Educational services are no exception, and rather, on the contrary, should have a personal website in the Arsenal of their promotion channels. The actively developing social network Instagram is also an excellent channel for marketing communication, so using it in your Arsenal of promotion, you can loudly declare yourself to your potential customers. However, only $10 \%$ of producers of additional educational services use this tool. As for other social networks, such as Facebook and Odnoklassniki, only a few have corporate community pages. This may be due to three factors: an inconvenient and incomprehensible interface (in contrast to the competitive social network Vkontakte); the opinion that it is enough to have a website and page; and ignorance of the properties of these sites.

The future of Internet promotion belongs to social networks, and we strongly recommend using each of them as fully as possible, because consumer flows can come through any, even the most unexpected communication channel. Nevertheless, despite this recommendation, keep in mind that before you organize an advertising campaign, you should understand who the target audience is and conduct marketing 
research, in particular, to identify where your consumers spend more time.

\section{Results}

Most of the children's centers are focused on providing additional sports services $-27 \%$. An important fact is that this category includes a wide variety of sports activities. It should be noted that this is a high concentration of sports sections with an excellent choice of suitable for each child, regardless of gender and age. Children's centers follow the latest trends in the market for providing active lifestyle services and offer their young consumers such interesting and quite new directions as yoga, cheerleading and acrobatic rock and roll. Of course, state budget institutions cannot boast of such a variety in the provision of services, as well as such a unique offer.

The next most popular category of additional services is the category-developmental classes from four to 7 years - $21 \%$, followed by the category of early development from one to 3 years - $15 \%$, which indicates that developmental classes for kids firmly occupy one of the main niches. If we consider these services in total and consider them as a category of developing classes for preschool children, then together we will get $36 \%$, which exceeds the category-sports sections. Here we can safely confirm the well-established fact of the last decade that intellectual development takes precedence over other areas of learning. In addition, educational institutions in pursuit of consumers are forced to identify their services from similar competitors and invent all new types of services that may interest the consumer. For example, fairy - tale therapy is presented only in one educational center for early development and distinguishes this educational institution from its competitors. As for the least represented categories, here you can see the distribution of $5 \%$ for two categories-foreign languages and music. Paradoxically, music classes for children take the last place in terms of availability of services. In addition, the Music category completely omits the possible unit of account for playing musical instruments, limiting the choice to vocals only. One can assume that when filling corporate electronic resources, service providers did not take into account that they bypassed music services. It is also possible that there is music training, but this is not indicated in the advertising message. If we focus on foreign language services, we do not see anything surprising here, since foreign language training in General education schools starts from the 5th grade and in specialized schools from the 2 nd grade, there is no need to increase the number of centers that provide such services.

In order for an educational institution to win in the competition, its services must be competitive in the market of additional preschool education.

Thanks to content analysis, we know the main directions of additional services in the preschool education market, as well as the main advantages that organizations use to position and promote themselves in a highly competitive market. When selecting categories of content analysis, we can conclude that all educational services have a number of characteristic features due to the specifics of the entire field of education as a whole.

During the analysis, five main semantic units of competitive advantages stated in the advertising message were identified: training program; cost; qualified personnel; individual approach; unique additional offer.

\section{Discussions}

Before determining the main preferences of consumers in relation to the study of additional preschool education services, it should be noted that all respondents gave a positive answer to the question whether their child received additional paid educational services. This means that out of the total number of respondents, each child is additionally engaged in at least one of the centers (sports sections, early development, choreography, etc.). Hence, we can conclude that the development of a child for young parents is one of the primary places, despite the mandatory payment for additional classes in one or another direction.

However, despite this, parents still take their children to additional education centers, which may indicate that the level of education in budgetary institutions is insufficient, as well as that the range and choice of additional classes in such institutions is extremely limited and does not meet the needs of modern parents. Especially popular are educational classes for children, which is $39 \%$ of the total number of responses received to the question: What additional paid classes does your child attend? We see that the most popular classes are choreography-23\% and sports sections-17\%, which is relevant at any time and at any age, since these classes not only contribute to obtaining certain skills, but also to strengthening the child's health, as well as the appearance of new acquaintances, which directly affects the socialization of the child in society. Less attendance is accounted for foreign language classes-7percentage; this may be due to two factors: preschool children, according to parents, are not ready to learn foreign languages due to their age; based on the results of content analysis, the representation of the foreign language category in the market of this area is extremely small4 percentage of all additional services provided. Accordingly, this leads to a low percentage of class attendance. The next missing element in the range of additional educational services is music classes. Based on the data obtained because of content analysis, music services covered only $4 \%$ compared to all other children's sections and clubs. It is difficult to justify this omission on the part of producers of educational services, because singing and playing musical instruments is not uncommon, in addition, it is not difficult to find teachers with musical education, as well as the instruments necessary for training. The main indicator for the justification of such classes is a serious demand from young parents $-23 \%$ of the number of respondents. In addition, when analyzing the results, there are quite interesting and rare wishes of parents for narrow specializations: gymnastics-5percentage, theater Studio6percentage, speech therapist-7percentage and pioneer2 percentage.

It should be noted that all respondents were quite loyal to the question of satisfaction and almost all responses were distributed within the answers completely satisfied and rather satisfied. The following indicators showed the highest level of satisfaction: the location of the educational institution; the schedule of classes; the result of the child's development after attending classes; the attitude of teachers to children.

\section{Conclusion}

Every developing person is in close interaction with education, regardless of age indicators. Education can be considered not only as a factor of socialization of a person, but also as a means of it, since it directly affects the choice of a person's future path, his/her profession, his/her selfdetermination and life values. Often, it is the education received by a person that is responsible for his/her lifestyle, and then for the norms of behavior. Based on this, education can be understood as a process and result of goal-oriented, pedagogically organized and planned socialization of a person, carried out in his/her interests and in the interests of the society to which he/she belongs.

In General, the importance of preschool education is often underestimated. It is too often overlooked that this is an 
extremely important stage in a person's life, where the Foundation of a person's personal qualities is laid.

Producers of additional educational services primarily focus their advertising messages on the cost of services, bringing this competitive advantage to the fore. It can be argued that the price of educational services plays a crucial role in choosing a particular children's training or sports center. According to representatives of educational services, the cost has a decisive influence on the purchase of services in the conditions of financial instability in modern Russia. In this regard, most educational institutions have invested in the content of their advertising messages the meaning of a relatively low cost of services compared to competitors.

In addition, most educational centers found it necessary to use information about highly qualified teaching staff in their advertising messages. Undoubtedly, this factor can be attributed not only to pre-school educational services, but also to the advantage of any educational institution.

A very serious aspect is that the future of online promotion is social networking, and one can recommend encouraging educational institutions to use each of them as fully, as the flow of customers can come from even the most unexpected communication channel.

One can conclude that a radical change in the essence of the education system, in turn, entailed an equally profound change in its content. Relatively slowly, but steadily, in accordance with the needs and capacities of society the network and hierarchy of educational and training institutions, ranging from preschools to higher education institutions, postgraduate education is transformed.

\section{Ethical issue}

Authors are aware of, and comply with, best practice in publication ethics specifically with regard to authorship (avoidance of guest authorship), dual submission, manipulation of figures, competing interests and compliance with policies on research ethics. Authors adhere to publication requirements that submitted work is original and has not been published elsewhere in any language.

\section{Competing interests}

The authors declare that there is no conflict of interest that would prejudice the impartiality of this scientific work.

\section{Authors' contribution}

All authors of this study have a complete contribution for data collection, data analyses and manuscript writing.

\section{References}

[1] Ivanova SP. Teacher of the XXI century: noopsychological approach to the analysis of professional and personal readiness for pedagogical activity. Pskov: Pskov state pedagogical University named after S.M. Kirov.2002

[2] Kuzmina NV. Professionalism of personality of a teacher and industrial training master. Moscow: Vysshaya shkola.1990

[3] Cherdymova EI. Substantiation of ecological consciousness structure for solving the problems of environmental education of the individual. Perspectives of science.2011;1(16):35-37.

[4] Latysheva VV, Bulgakova VO, Sidorenko GG, Korenko JM, Khairullina ER, Shaidullina AR, Bayanova AR Subjective environmental attitude features to nature of specially protected areas employees. Ekoloji.2018;27(106):1801-1808

[5] Ilyasov II. Structure of the learning process. Moscow: MSU.1986

[6] Ilyushin LS. Educational motivation: theory and methodology of research. Saint Petersburg: BAN publishing house.2002

[7] Zymnaya IA. Educational psychology. Textbook. Rostov-on-don: Phoenix.1997
[8] Zhuravlev VI. Pedagogy in the system of human Sciences. Moscow: Pedagogy.1990

[9] Andreeva AF. Marketing of educational institutions. Professional education.2003;8:22-31.

[10] Platonova NM. Fundamentals of social pedagogy. Saint Petersburg: Saint Petersburg University.1997

[11]Potolitsina LF. Socially oriented marketing of educational services. Professional education.2006;6:23-35.

[12] Bayanova AR, Sivova IV, Kamasheva YL, Popova OV, Semyanov EV, Shagieva RV, Yusupov IM. Student online services consumption: Routine practices or mistrust to digital service? Contemporary Educational Technology.2020;11(1): 47-54.

[13] Khairullina ER, Shubovich MM, Bogdanova VI, Slepneva EV, Mashkin NA, Rodyukova TN. Modern student youth civic identity: Political activity or social responsibility? Opcion.2020; 36:1703-1717.

[14] Olkhovaya TA, Cherdymova EI, Merculova LV, Manakova OS, Sukhodolova EM, Laptev AA, Popova OV. Development features of students communicative focus. Modern Journal of Language Teaching Methods.2019;9(1):78-89.

[15] Podymov NA, Nikoghosyan MA, Stolyarova AN, Narutto SV, Mashkin NA, Martynenko SE, Paznikova ZI, Varenik PK. University New Educational Reality in Disruptive Technologies Context. Journal of Environmental Treatment Techniques.2019; 7(4): 664-668.

[16] Shevchenko DA. Marketing research of the educational services market in Russia. Marketing in Russia and abroad.2005;4:36-42.

[17] Cherdymova EI. Innovative technologies in the formation of ecological consciousness in preschool children. Proceedings of the Samara scientific center of the Russian Academy of Sciences.2010; 12(5):163-167.

[18] Saganov SA. Marketing of educational services in the region. Marketing in Russia and abroad.2003;5:23-25.

[19] Kovaleva GS. Monitoring the quality of education based on educational standards. Quality control and evaluation in education: Proceedings of the international conference. Saint Petersburg: publishing house of A.I. Herzen Russian state pedagogical University. 1998

[20]Pikelnaya VS. Theoretical foundations of management. Moscow: Higher school.1990

[21] Cherdymova EI. Ecology of childhood. Childhood of the XXI century: socio-humanitarian thesaurus. Thematic dictionaryreference. Moscow:ROS. 2018

[22] Bayanova AR, Vodenko KV, Sizova ZM, Chistyakov AA, Prokopyev AI, Vasbieva DG. A philosophical view of organizational culture policy in contemporary universities. European Journal of Science and Theology.2019;15(3):121-131.

[23] Shishov SYe, Kalney VA. Monitoring the quality of education in schools. Moscow: RPA. 1998.

[24] Valiev ShZ, Sukhochev VI. Market of educational services: theoretical aspects. Ufa: Design Polygraph Service.2008.

[25] Narutto SV, Cherdymova EI, Sokolova ED, Savostyanova SA, Stolyarova AN, Vilskaya NV, Konovalova IA, Smirnova EA. First-Year Student Attitude to Social Networks. International Journal of Applied Exercise Physiology.2019;8(2):273-276.

[26] Samsonova MV, Samsonova YeZ. Features of marketing interaction in the educational services market. VSU Proceedings.2012;9(73):114-118

[27] Slastenin VA, Podymova LS. Pedagogy: innovative activity. Moscow: Magistr.1997.

[28]Lebedev OE. Management of educational systems. V. Novgorod: Nenets regional center for education development. 1998.

[29] Avdeev VA, Avdeeva OA, Shagieva RV, Smirnova VV, Mashkin NA, Taradonov SV. The mechanism of legal regulation in the conditions of globalization and formation of information environment. Regional aspect. Journal of Environmental Management and Tourism.2019;10(7):1517-152.

[30] Mipyayeva LR. Marketing research on educational services market in provincial cities (on the example of institutions of higher professional education). Marketing in Russia and abroad.2005;5:33-39.

[31] Vitalieva VA, Vitalieva EM. Marketing mechanism of influence on the consumer of educational services. International research journal.2013;12(19):13-20. 
[32] Arutyunova AE. Market tools for educational services development. Krasnodar: publishing house of Management Southern Institute. Krasnodar.2010

[33] Ovsyanik AI, Sidorenko GG, Prasolov VI, Aleksandrova NS, Mashkin NA, Pozdnyakova IR, Makarova EV. Remote education in modern university: Potential opportunities, quality or availability? International Journal of Psychosocial Rehabilitation.2020; 24(4):5027-5034.

[34] Saganova OV. Marketing of educational services. Marketing in Russia and abroad.2005;3:48-59.

[35]Zhgenti IV, Kuznetsova VV, Savinov AM, Gribova OE, Sidyacheva NV and Prokopyev AI. Modern integration processes influence on educator's professional growth. Espacios.2018;39(2);13. 